\title{
Chromosome numbers of Australian and New Guinean species of Veronica (Plantaginaceae)
}

\author{
Barbara G. Briggs ${ }^{1}$ and Friedrich Ehrendorfer ${ }^{2}$ \\ ${ }^{1}$ Botanic Gardens Trust Sydney, Mrs Macquaries Road, Sydney NSW 2000, Australia. \\ Email:barbara.briggs@rbgsyd.nsw.gov.au \\ ${ }^{2}$ Institute of Botany, University of Vienna, Rennweg 14, A-1030, Vienna, Austria. \\ Email: friedrich.ehrendorfer@univie.ac.at
}

\begin{abstract}
New records of chromosome numbers are presented for eleven Australian species of Veronicasens. lat. Reference is also given to records previously published for ten species that have been referred to Derwentia, Parahebe or Chionohebe, but that are now included in a widely circumscribed Veronica. The species formerly included in Derwentia, Parahebe or Chionohebe exhibit secondary base numbers of $x=21,20$ or 19, whereas those formerly retained in Veronica have $x=18$ (or 17). For the species formerly referred to Detzneria, from New Guinea, we present only a very approximate count of $2 n=38-42$ which, however, differs from the previous report of $2 n=48$.
\end{abstract}

\section{Introduction}

Differences in chromosome number have long been regarded as an important feature in characterising genera within Veroniceae (Frankel 1941, Frankel \& Hair 1937, Garnock-Jones 1993). Chromosome numbers for most of the Australian and one New Guinean species are presented here (Table 1), making them available for a compilation of karyological data for Veroniceae (Albach et al. submitted). Information on the New Zealand taxa is given by Dawson (2000) while Bayly and Kellow (2006) provide a revised and updated list of chromosome numbers for species formerly included in Hebe or Leonohebe. New taxa and taxonomic notes on these Australian taxa are presented by Briggs and Ehrendorfer (2006) in this issue of Telopea. Chromosome numbers for most of the Australian species formerly included in Derwentia or Parahebe have been reported already by Briggs and Ehrendorfer (1992); references to these reports are included here, giving the names and authorities (as in Garnock-Jones et al. submitted), now that they will be included in an enlarged Veronica. For four species ('V. arcuata', 'V. blakelyi', ' $V$. lithophila' and ' $V$. tubata'), as well as the subspecies of $V$. derwentiana and most of the Southern Hemisphere sections within Veronica, valid publication of the new combinations will await Garnock-Jones et al. (submitted). 


\section{Methods}

The new counts are mostly somatic numbers, determined on root-tip material, using 130 minutes of pre-fixation treatment with saturated aqueous $p$-dichlorobenzene and staining with alcoholic carmine (Snow 1963). Plants transplanted from the wild were grown at the Royal Botanic Gardens Sydney. In most cases, the number reported was counted from several cells. For ' $V$. tubata', however, only a small amount of wild-collected stem and leaf meristematic tissue was available and only approximate counts were obtained. In that case, the chromosomal spreads (of several cells) were far from ideal but the result is included since it differed from what had been previously reported.

\section{Results}

The new findings and reference to previous reports are presented in Table 1. Voucher specimens and their collectors are cited.

\section{Discussion}

The findings are mostly consistent with previous reports (Briggs \& Ehrendorfer 1992), in that the species formerly included in the genera Derwentia (' $V$. arcuata', V. arenaria, ' $V$. blakelyi, V. decorosa, V. derwentiana, V. nivea, V. perfoliata, ' $V$. velutina'), Parahebe (' $V$. lithophila'), Chionohebe ( $V$. densifolia) and one previously of uncertain generic position ( $V$. formosa) have numbers of $x=19,20$ or 21 . These species are here referred to the Derwentia clade and the $V$. formosa clade within 'Veronica sect. Derwentia' and the Chionohebe clade within sect. Hebe (Briggs \& Ehrendorfer 2006, Garnock-Jones et al. submitted). By contrast, all records for the Australian species formerly retained in Veronica show secondary base numbers of $x=17$ or 18 and are placed in the V. calycina clade of 'sect. Derwentia'. For Veronica tubata, the sole member of ' $V$. sect. Detzneria', only a very approximate count of $2 n=38-42$ is reported, but it is a finding different from the previously reported count of $2 n=48$ (Borgmann 1964).

Wagstaff et al. (2002) showed that, from analysis of ITS DNA data, 'Veronica lithophila' (then known as Parahebe lithophila) grouped more closely with species of Derwentia than with V.calycina or with the New Zealand species then placed in Parahebe and that are now referred to Veronica sect. Hebe. The chromosome number $2 n=42$ does not assist in resolving its subgeneric position, but supports its placement in the Derwentia clade, rather than the V. calycina clade, within Veronica 'sect. Derwentia'. We take this opportunity to correct a previous error concerning V. lithophila. Garnock-Jones has drawn attention to the folded lateral corolla lobes of Parahebe as a distinguishing feature of the genus. When describing this species (Briggs \& Ehrendorfer 1992) we included a photo supposedly illustrating this feature in newly-opened flowers of $P$. lithophila and we considered this feature to be among those identifying it as a species of Parahebe. We were later advised that the photo was not of this species, as we had understood, but of cultivated plants of a New Zealand species. Veronica lithophila has flat lateral corolla lobes, as in Derwentia species. 
In agreement with Albach et al. (submitted), we hypothesise that the chromosome numbers of the Southern Hemisphere Veronica species of sect. 'Derwentia' and sect. Hebe have been derived from $x=8$, characteristic for the most closely related Northern Hemisphere $V$. subgenus Chamaedrys. If the previous record of $2 n=48$ for the monospecific V. 'sect. Detzneria' (formerly Detzneria tubata) in New Guinea is correct, the secondary hexaploid base number $x=24$, is still maintained. Our finding, of $2 n=38-42$ for this species, however, although only approximate, suggests that dysploid change $(x=8 \rightarrow 7)$ may have preceded polyploidy or that only dysploid levels may now exist. From the hexaploid level, stepwise descending dysploidy could have resulted in $x=21 \rightarrow 20 \rightarrow 19 \rightarrow 18 \rightarrow 17$, the secondary base numbers found in the remaining Southern Hemisphere sections of Veronica. The evolutionary history may, however, be somewhat more complex since a number of reports deviate from multiples of these base numbers. Also, Bayly and Kellow (2006) observe that polyploidy is found 'within at least some species [of the New Zealand species of $V$. sect. Hebe and] it seems likely that independent origins of polyploidy have been relatively common'.

The patterns of different chromosome numbers tend to be obscured by inclusion of all these clades in an enlarged Veronica, but the previous classification was untenable if only monophyletic groups are to be recognised, as discussed by Garnock-Jones et al. (submitted).

\section{References}

Albach, DC, Martínez-Ortega MM, Delgado L, Weiss-Schneeweiss HF, Özgökce F \& Fischer MA (2006 submitted) Chromosome numbers in Veroniceae: review and several new counts. Annals of the Missouri Botanical Garden

Bayly MJ, Kellow AV (2006) An illustrated guide to New Zealand Hebes. (Te Papa Press: Wellington)

Borgmann E (1964) Anteil der Polyploiden in der Flora des Bismarckgerbirges von Ostneuguinea. Zeitschrift für Botanik 52: 118-172.

Briggs BG \& Ehrendorfer F (1992) A revision of the Australian species of Parahebe and Derwentia (Scrophulariaceae). Telopea 5: 241-287.

Briggs BG \& Ehrendorfer F (2006) New Australian species and typifications in Veronica s. lat. (Plantaginaceae). Telopea 11(3): 276-292.

Briggs BG \& Makinson RO (1992) Parahebe. P. 574 in Harden GJ (ed.) Flora of New South Wales, vol. 3. (New South Wales University Press: Kensington)

Dawson MI (2000) Index of chromosome numbers of indigenous New Zealand spermatophytes. New Zealand Journal of Botany 38: 47-150.

Frankel OH (1941) Cytology and taxonomy of Hebe, Veronica and Pygmaea. Nature 146: 117.

Frankel OH \& Hair JB (1937) Studies on the cytology, genetics, and taxonomy of New Zealand Hebe and Veronica (Part 1). New Zealand Journal of Science and Technology 18: 669-687.

Garnock-Jones PJ (1993) Phylogeny of the Hebe complex (Scrophulariaceae; Veroniceae). Australian Systematic Botany 6: 457-479.

Garnock-Jones PJ, Albach DC and Briggs BG (2006 submitted). Botanical names in Veronica sect. Derwentia, sect. Detzneria and sect. Hebe (Plantaginaceae). Taxon.

Snow R (1963) Alcoholic hydrochloric acid-carmine as a stain for chromosomes in squash preparations. Stain Technology 38: 9-13. 
Table 1. Chromosome numbers reported for Australian and a New Guinean species of Veronica, new findings and reference to previous records. Combinations at sectional, species and subspecies rank indicated as 'ined.' will be published in Garnock-Jones et al. (submitted).

\begin{tabular}{|c|c|c|c|c|c|}
\hline Taxon & $n$ & $2 n$ & $\begin{array}{l}\text { Voucher } \\
\text { (Herb. NSW) }\end{array}$ & Collector & $\begin{array}{l}\text { Locality or } \\
\text { reference }\end{array}$ \\
\hline \multicolumn{6}{|c|}{ 'Veronica sect. Derwentia (Raf.) B.G.Briggs' ined. } \\
\hline \multicolumn{6}{|c|}{ V. calycina clade } \\
\hline $\begin{array}{l}\text { Veronica brownii } \\
\text { Roem. \& Schult. }\end{array}$ & & 72 & 118260 & B. Briggs & Blackheath Glen, NSW \\
\hline Veronica calycina R.Br. & & 36 & 84539 & $\begin{array}{l}\text { L. Johnson \& } \\
\text { B. Briggs } 1058\end{array}$ & near Mt Werong, NSW \\
\hline Veronica distans R.Br. & & 72 & 95339 & F. Ehrendorfer 17601 & Hamelin Bay, WA \\
\hline Veronica gracilis R.Br. & & c. 72 & 97476 & R. Coveny 903 & $\begin{array}{l}\text { Wingecarribee Swamp, } \\
\text { NSW }\end{array}$ \\
\hline $\begin{array}{l}\text { Veronica grosseserrata } \\
\text { B.G.Briggs \& Ehrend. }\end{array}$ & & $\begin{array}{l}72 \\
72\end{array}$ & $\begin{array}{l}95319 \\
95276\end{array}$ & $\begin{array}{l}\text { R. Coveny } \\
\text { A. Rodd } 380\end{array}$ & $\begin{array}{l}\text { Gloucester Tops, NSW } \\
\text { Mountain Creek, Vic. }\end{array}$ \\
\hline $\begin{array}{l}\text { Veronica hillebrandii } \\
\text { F.Muell. }\end{array}$ & & 36 & 101772 & A. Rodd & $\begin{array}{l}\text { cultivated ex South } \\
\text { Australia }\end{array}$ \\
\hline $\begin{array}{l}\text { Veronica notabilis } \\
\text { F.Muell. ex Benth. }\end{array}$ & & 36 & 255756 & B. Briggs 3989 & Brown Mountain, NSW \\
\hline Veronica plebeia R.Br. & & $\begin{array}{l}34 \\
34 \\
34\end{array}$ & $\begin{array}{l}240439 \\
118263 \\
95314\end{array}$ & $\begin{array}{l}\text { F. Ehrendorfer } 18301 \\
\text { B. Briggs } \\
\text { R. Coveny }\end{array}$ & $\begin{array}{l}\text { Porongorup Mts, WA } \\
\text { Megalong Valley, NSW } \\
\text { Copeland, NSW }\end{array}$ \\
\hline $\begin{array}{l}\text { Veronica sobolifera } \\
\text { B.G.Briggs \& Ehrend. }\end{array}$ & & 72 & 98196 & R. Coveny & Gloucester Tops, NSW \\
\hline $\begin{array}{l}\text { Veronica subtilis } \\
\text { B.G.Briggs \& Ehrend. }\end{array}$ & & 36 & 95757 & B. Briggs 1082 & Tomat Swamp, NSW \\
\hline \multicolumn{6}{|c|}{ Derwentia clade } \\
\hline $\begin{array}{l}\text { 'Veronica arcuata } \\
\text { (B.G.Briggs \& Ehrend.) } \\
\text { B.G.Briggs' ined. }\end{array}$ & & 42 & 96611 & J. Williams & $\begin{array}{l}\text { Bullock Creek, E of } \\
\text { Armidale, NSW }\end{array}$ \\
\hline $\begin{array}{l}\text { Veronica arenaria } \\
\text { A. Cunn. ex Benth. }\end{array}$ & 19 & 38 & 95685 & F. Ehrendorfer et al. & $\begin{array}{l}\text { Briggs \& Ehrendorfer } \\
\text { (1992), as Derwentia } \\
\text { arenaria }\end{array}$ \\
\hline $\begin{array}{l}\text { 'Veronica blakelyi } \\
\text { (B.G.Briggs \& Ehrend.) } \\
\text { B.G.Briggs' ined. }\end{array}$ & & 42 & 101598 & B. Briggs 1058 & Clarence, NSW \\
\hline $\begin{array}{l}\text { Veronica decorosa } \\
\text { F.Muell. }\end{array}$ & 19 & 38 & 97485 & Hj. Eichler & $\begin{array}{l}\text { Briggs \& Ehrendorfer } \\
\text { (1992), as D. decorosa }\end{array}$ \\
\hline
\end{tabular}




\begin{tabular}{|c|c|c|c|c|c|}
\hline Taxon & $n$ & $2 n$ & $\begin{array}{l}\text { Voucher } \\
\text { (Herb. NSW) }\end{array}$ & Collector & $\begin{array}{l}\text { Locality or } \\
\text { reference }\end{array}$ \\
\hline $\begin{array}{l}\text { Veronica derwentiana, } \\
\text { subsp. not recorded, } \\
\text { probably subsp. } \\
\text { derwentiana }\end{array}$ & 20 & & & O. Frankel & $\begin{array}{l}\text { Briggs \& Ehrendorfer } \\
(1992) \text {, as } \\
\text { D. derwentiana }\end{array}$ \\
\hline $\begin{array}{l}\text { 'Veronica derwentiana } \\
\text { subsp. homalodonta } \\
\text { (B.G.Briggs \& Ehrend.) } \\
\text { B.G.Briggs' ined. }\end{array}$ & & 40 & 118325 & McArthur & $\begin{array}{l}\text { Briggs \& Ehrendorfer } \\
\text { (1992), as } \\
\text { D. derwentiana } \\
\text { subsp. homalodonta }\end{array}$ \\
\hline $\begin{array}{l}\text { 'Veronica derwentiana } \\
\text { subsp. subglauca } \\
\text { (B.G.Briggs \& Ehrend.) } \\
\text { B.G.Briggs' ined. }\end{array}$ & & 40 & 101605 & $\begin{array}{l}\text { B. Briggs } 1011 \text { \& } \\
\text { L. Johnson }\end{array}$ & $\begin{array}{l}\text { Briggs \& Ehrendorfer } \\
\text { (1992), as } \\
\text { D. derwentiana } \\
\text { subsp. subglauca }\end{array}$ \\
\hline $\begin{array}{l}\text { 'Veronica lithophila } \\
\text { (B.G.Briggs \& } \\
\text { Ehrendorfer) } \\
\text { B.G.Briggs' ined. }\end{array}$ & & $\begin{array}{l}42 \\
42\end{array}$ & $\begin{array}{l}84562 \\
98192\end{array}$ & $\begin{array}{l}\text { B. Briggs } 1125 \\
\text { A. Rodd } 517\end{array}$ & $\begin{array}{l}\text { Briggs \& Ehrendorfer } \\
\text { (1992), as } \\
\text { Parahebe lithophila }\end{array}$ \\
\hline Veronica nivea Lindl. & & 40 & & F. Ehrendorfer & $\begin{array}{l}\text { Briggs \& Ehrendorfer } \\
\text { (1992), as D. nivea }\end{array}$ \\
\hline $\begin{array}{l}\text { Veronica perfoliata } \\
\text { R.Br. }\end{array}$ & 20 & 40 & 854491 & L. Johnson & $\begin{array}{l}\text { Briggs \& Ehrendorfer } \\
(1992) \text {, as } \\
\text { D. perfoliata }\end{array}$ \\
\hline $\begin{array}{l}\text { 'Veronica velutina } \\
\text { (B.G.Briggs \& Ehrend.) } \\
\text { B.G.Briggs' ined. }\end{array}$ & & $40+$ & 258899 & $\begin{array}{l}\text { B. Briggs } 4298 \text { \& } \\
\text { L. Johnson }\end{array}$ & $\begin{array}{l}\text { Mt Kaputar plateau, } \\
\text { NSW }\end{array}$ \\
\hline
\end{tabular}

\section{V. formosa clade}

Veronica formosa R.Br. $21 \quad 42$

O. Frankel M. Phillips

Briggs \& Ehrendorfer (1992)

Veronica sect. Hebe (Juss.) G.Don

Chionohebe clade

Veronica densifolia

(F.Muell.) F.Muell.

$42+\quad 124420 \quad$ B. Briggs 2631

Mt Northcote, NSW

'Veronica sect. Detzneria' (Schltr. ex Diels) Albach ined.

\begin{tabular}{|c|c|c|c|c|}
\hline $\begin{array}{l}\text { 'Veronica tubata (Diels) } \\
\text { Albach'ined. }\end{array}$ & $\begin{array}{l}38-42 \\
48\end{array}$ & 249793 & B. Briggs 3747 & $\begin{array}{l}\text { Mt Wilhelm, Papua } \\
\text { New Guinea } \\
\text { Boramann (1964) }\end{array}$ \\
\hline
\end{tabular}

† Chromosome numbers that were reported by Briggs \& Ehrendorfer (1992), but without citation of the voucher specimen. 